\title{
Preparation and Reactions of Sulfur-Nitrogen Ring Systems*
}

\author{
Herbert W. Roesky \\ Anorganisch-chemisches Institut der Universität Frankfurt \\ (Z. Naturforsch. 31 b, 680-683 [1976]; received August 12, 1975) \\ X-ray, Sulfur-nitrogen Ring Systems, Silicon
}

\begin{abstract}
Two routes for the preparation of $\left(\mathrm{CH}_{3}\right)_{2} \mathrm{SnS}_{2} \mathrm{~N}_{2}$ are given, which are kinetically controlled reactions. The molecule $\left(\mathrm{CH}_{3}\right)_{2} \mathrm{SnS}_{2} \mathrm{~N}_{2}$ was characterized by $\mathrm{X}$-ray analysis. It is an interesting starting material for the preparation of $\mathrm{S}_{2} \mathrm{~N}_{2} \mathrm{CO}$ and $\mathrm{S}_{3} \mathrm{~N}_{2} \mathrm{O}$. The latter reacts with iminosulfur oxides and isocyanates under the formation of $\mathrm{S}_{3} \mathrm{~N}_{3} \mathrm{SO}_{2} \mathrm{~F}$ and $\mathrm{S}_{3} \mathrm{~N}_{3} \mathrm{SO}_{2} \mathrm{CF}_{3}$. The structure of $\mathrm{S}_{3} \mathrm{~N}_{3} \mathrm{SO}_{2} \mathrm{~F}$ was established by $\mathrm{X}$-ray analysis. The bonding properties are discussed.

The cleavage of thin-nitrogen derivatives with $\mathrm{S}_{3} \mathrm{~N}_{2} \mathrm{Cl}_{2}$ yields also five membered sulfurnitrogen rings. The structure and properties of $\mathrm{P}_{3} \mathrm{~N}_{3} \mathrm{~F}_{5} \mathrm{NS}_{3} \mathrm{~N}_{2}$ and $\mathrm{C}_{3} \mathrm{~N}_{3} \mathrm{~F}_{2} \mathrm{NS}_{3} \mathrm{~N}_{2}$ are reported. Six, eight and ten membered rings are formed by the reactions of

$\left(\mathrm{CH}_{3}\right)_{3} \mathrm{Si}-\mathrm{N}=\mathrm{S}=\mathrm{N}-\mathrm{Si}\left(\mathrm{CH}_{3}\right)_{3}$

with $\mathrm{FSO}_{2}-\mathrm{N}=\mathrm{S}=\mathrm{O}$, these are $\mathrm{S}_{4} \mathrm{~N}_{4} \mathrm{O}_{2}$ and $\mathrm{S}_{5} \mathrm{~N}_{5}+\mathrm{S}_{3} \mathrm{~N}_{3} \mathrm{O}_{4}{ }^{-}$, respectively. The cation $\mathrm{S}_{5} \mathrm{~N}_{5}{ }^{+}$ is a planar molecule, while the oxygen containing species are puckered. In $\mathrm{S}_{4} \mathrm{~N}_{4} \mathrm{O}_{2}$ the oxygens are attached to one sulfur atom, which has a tetrahedral configuration.

The structure of the silicon containing cyclic and bicyclic rings $\left(\mathrm{CH}_{3}\right)_{2} \mathrm{Si}(\mathrm{NSN})_{2} \mathrm{Si}\left(\mathrm{CH}_{3}\right)_{2}$ and $\mathrm{CH}_{3} \mathrm{Si}(\mathrm{NSN})_{3} \mathrm{SiCH}_{3}$ were determined.
\end{abstract}

Although tetrasulfur tetranitride was prepared 140 years ago, little is known about other kinetically controlled reactions in this field ${ }^{1}$. The preferred method for preparing $\mathrm{S}_{4} \mathrm{~N}_{4}$ is the reaction of sulfur chlorides having a composition " $\mathrm{SCl}_{3}$ " with ammonia. $\mathrm{SCl}_{3}$ is not known and therefore $\mathrm{SCl}_{2}$ is treated in carbon tetrachloride solution with chlorine.

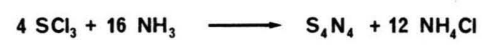

Recently we used tin substitued amines instead of ammonia because the $\mathrm{N}-\mathrm{H}\left(391 \mathrm{~kJ} \mathrm{~mol}^{-1}\right)$ bond energy is significantly greater than the tin-nitrogen bond energy (e.g. in $\left.\left(\mathrm{CH}_{3}\right)_{3} \mathrm{SnN}\left(\mathrm{CH}_{3}\right)_{2} 167 \mathrm{~kJ} \mathrm{~mol}^{-1}\right)$. Thus, other cyclic derivatives should be easy available from the reaction of tin-nitrogen compounds with inorganic halides. It should be added that in addition the formation of a tin-halogen bond is favoured ${ }^{2}$.

* Paper, presented at the 1. International Symposium on Inorganic Heterocycles, Besançon (France), June 16-19, 1975.

Requests for reprints should be sent to Prof. Dr. H. W. Roesky, Anorganisch-chemisches Institut I der Universität, Niederurseler Hang, D-6000 Frankfurt a.M.

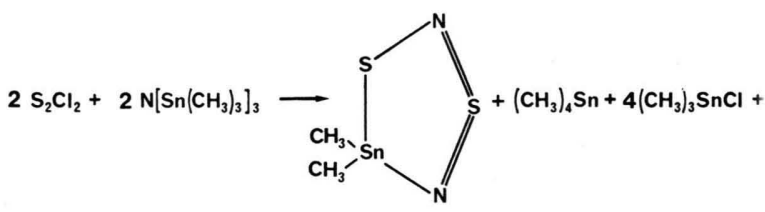

By using $\mathrm{N}\left[\mathrm{Sn}\left(\mathrm{CH}_{3}\right)_{3}\right]_{3}$ as a nucleophile, it is also possible to get to the same product according to the following equations ${ }^{3,4}$.

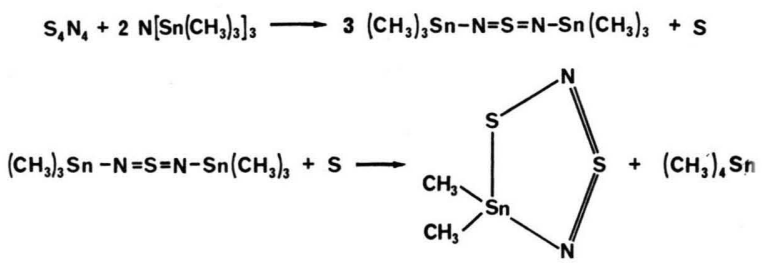

The intermediates, sulfur and the tin substituted sulfur diimide, $\left(\mathrm{CH}_{3}\right)_{3} \mathrm{Sn}-\mathrm{N}=\mathrm{S}=\mathrm{N}-\mathrm{Sn}\left(\mathrm{CH}_{3}\right)_{3}$, might be obtained before heating the reaction mixture. The structure of the cyclic tin compound $\left(\mathrm{CH}_{3}\right)_{2} \mathrm{SnS}_{2} \mathrm{~N}_{2}$ has been determined ${ }^{5}$, the molecule existed of one four-membered and two five-mem. bered rings and the coordination number at the tin is five as shown below. The molecule has $\mathrm{C}_{\mathbf{i}}$ symmetry. 


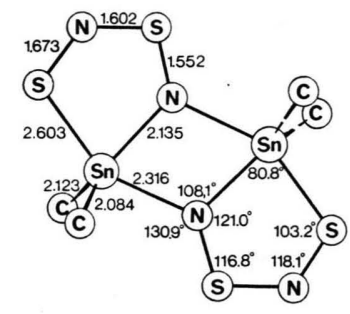

The molecule is also a dimer in solution but monomeric in the gas phase. Another interesting feature of the structure is, that the molecule has nearly a planar form in the solid state. All the $\mathrm{S}-\mathrm{N}$ bonds are of different length, the N-S-N and S-N-S bond angles being $116.8^{\circ}$ and $118.1^{\circ}$, respectively. The bond lengths are intermediate between that expected for a single (1.74 $\AA$ ) and a double bond $(1.54 \AA)$. Comparing the Sn-S-N angle of $103.2^{\circ}$ with the N-S-N angle of $116.8^{\circ}$ a significantly difference is observed, which is caused by different electron density. This iliustrates that it is to some extent justified to assign a formal oxidation number of +2 for the sulfur bonded to tin and a formal oxidation number of +4 for the sulfur atom located between the two nitrogen atoms. Recent work has shown that $\mathrm{COF}_{2}{ }^{6}$ or $\mathrm{SOF}_{2}{ }^{7}$ react at room temperature with the tin compound under insertion and elimination of dimethyltindifluoride.

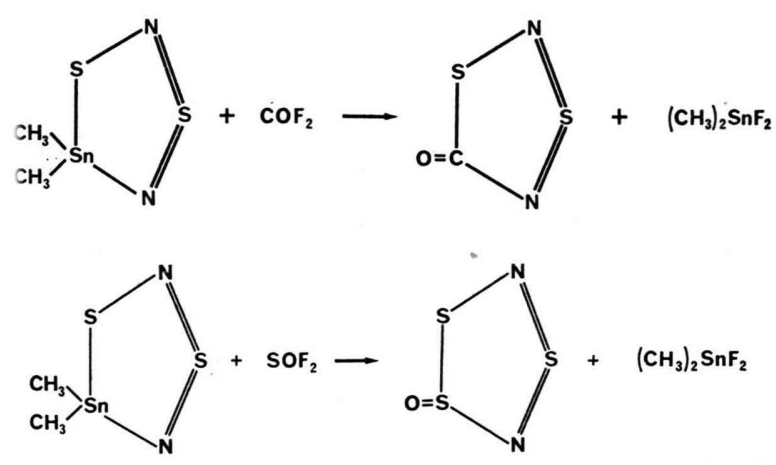

The cyclic ketone is the first representative of a new class of compounds that have become readily ucessible by this method. $\mathrm{COCl}_{2}$ reacts similarly, but separation of the ketone from the dimethylindichloride proves difficult. The use of fluoro lerivatives is favoured by forming solid non-volatile in-fluorides. The ketone is a yellow crystalline sompound with m.p. $40.5{ }^{\circ} \mathrm{C}$ and it can be sublimed $\mathrm{n}$ vacuum at room temperature.
The five-membered sulfur-nitrogen oxide shown above is a red oil at room temperature. The chemistry of this compound 8 is essentially that associated with the SO group, which undergoes a number of the normal reactions of organic sulfur oxides.

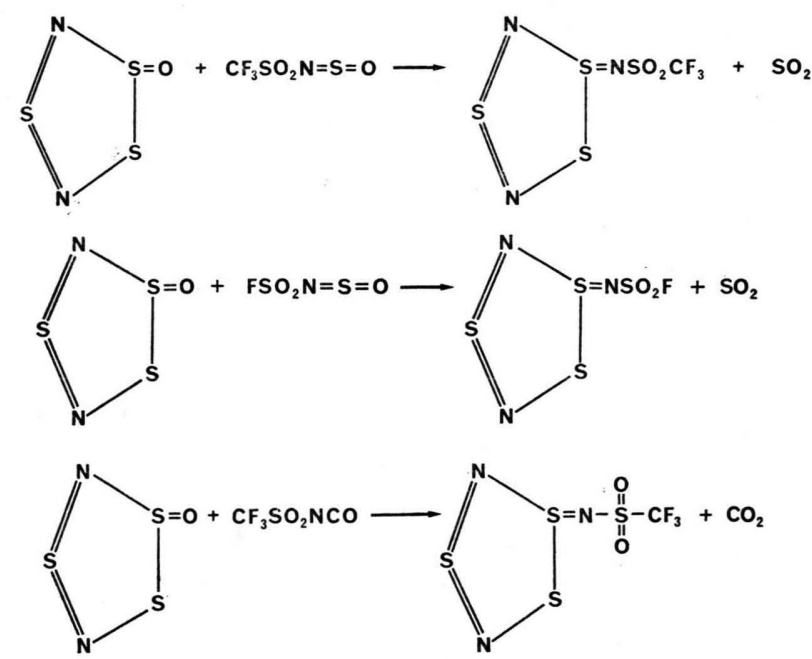

Iminosulfur oxides and isocyanates react under evolution of $\mathrm{SO}_{2}$ and $\mathrm{CO}_{2}$ respectively. The structure of the fluorosulfonyl derivative has been determined by X-ray analysis 5 .

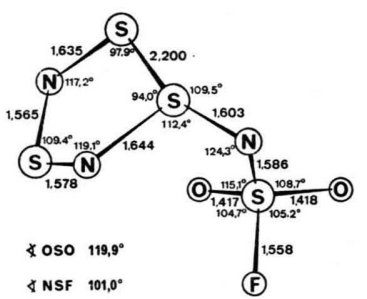

The interesting feature of this structure is, that the exocyclic $\mathrm{N}-\mathrm{S}$ bond adjacent to the five membered ring with a bond length of $1.603 \AA$ is greater than the $\mathrm{O}_{2} \mathrm{~S}-\mathrm{N}$ bond with distance of $1.586 \AA$.

These structural data confirm that the compound is partly ionic and might be assumed having an intermediate between the covalent and ionic form shown below.

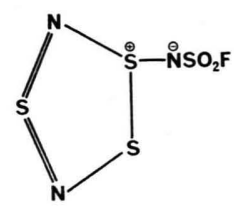


By using the well-known compound $\mathrm{S}_{3} \mathrm{~N}_{2} \mathrm{Cl}_{2}$ as a starting material and nitrogen-tin derivatives we were able to isolate bicyclic compounds ${ }^{9,10}$.

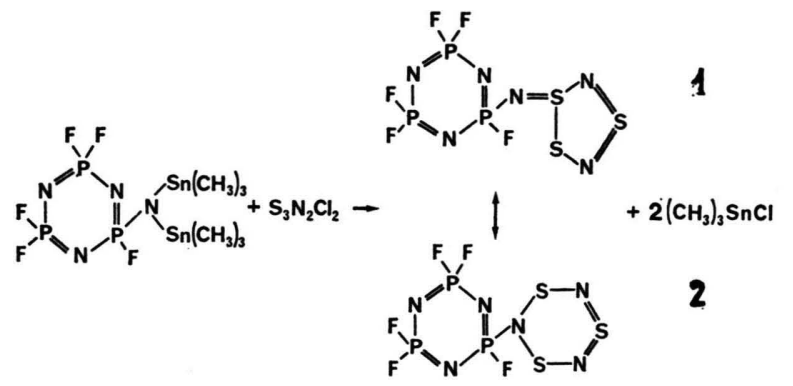<smiles></smiles>

The question however, whether isomer 1 or $\mathbf{2}$ is formed has been established by X-ray analysis ${ }^{11}$. It is found that the formation of the five-membered ring is favoured. By comparing the data of the $\mathrm{S}_{3} \mathrm{~N}_{2} \mathrm{Cl}^{+}$cation ${ }^{12}$ with the $\mathrm{N}-\mathrm{S}_{3} \mathrm{~N}_{2}$ part of $\mathrm{P}_{3} \mathrm{~N}_{3} \mathrm{~F}_{5} \mathrm{NS}_{3} \mathrm{~N}_{2}$ we observe that,
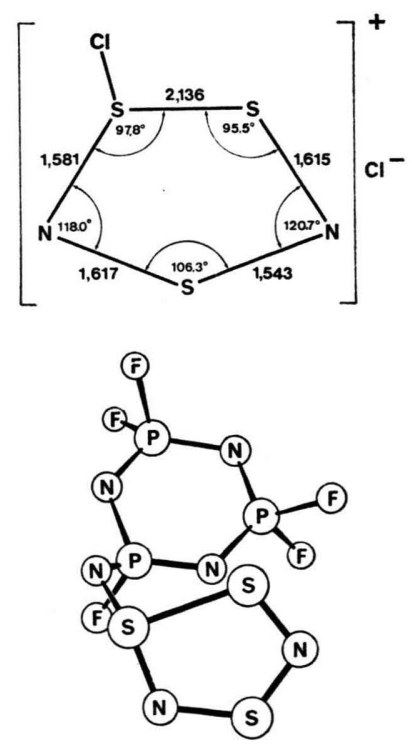

$\mathrm{P}_{3} \mathrm{~N}_{3} \mathrm{~F}_{5}-\mathrm{N}-\mathrm{S}_{3} \mathrm{~N}_{2}$

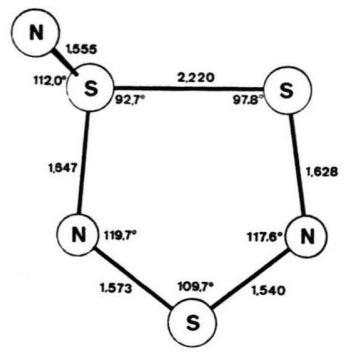

the S-S distance is considerably longer $2.200 \AA$ than in the cation $2.136 \AA$. The electron density is apparently much higher. A further point of interest is, that the $6 \pi$-electron $\mathrm{S}_{2} \mathrm{~N}_{2}$ part is not substantially influenced. It was confirmed by calculations on $\mathrm{S}_{3} \mathrm{~N}_{2} \mathrm{Cl}+$ that the ring may formally be regarded as a pseudo-aromatic $6 \pi$-electron system ${ }^{13}$. Many compounds with S-N bonds may, of course, be synthesized from silicon-nitrogen derivatives. Typical of these is $\left(\mathrm{CH}_{3}\right)_{3} \mathrm{Si}-\mathrm{N}=\mathrm{S}=\mathrm{N}-\mathrm{Si}\left(\mathrm{CH}_{3}\right)_{3}$. On reaction with $\mathrm{CH}_{3} \mathrm{SiCl}_{3}$ and the corresponding tin derivative the bicyclic silicon-sulfur-nitrogen compound is formed ${ }^{14}$.

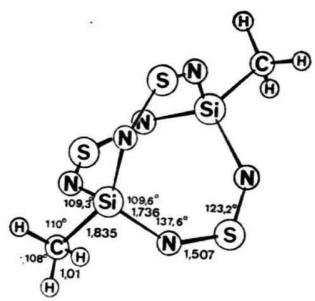

The molecule has exact $\mathrm{D}_{3}$-symmetry ${ }^{5}$. A related compound is obtained by using $\left(\mathrm{CH}_{3}\right)_{2} \mathrm{SiCl}_{2}{ }^{15}$. The eight-membered ring was confirmed by X-ray analysis ${ }^{16}$. Both compounds are sensitive to moisture but can be sublimed without reduced pressure.

The products shown in the figures below resulted from the reaction of $\left(\mathrm{CH}_{3}\right)_{3} \mathrm{Si}-\mathrm{N}=\mathrm{S}=\mathrm{N}-\mathrm{Si}\left(\mathrm{CH}_{3}\right)$ : with $\mathrm{FSO}_{2}-\mathrm{N}=\mathrm{S}=\mathrm{O}$ in methylenechloride ${ }^{17}$.

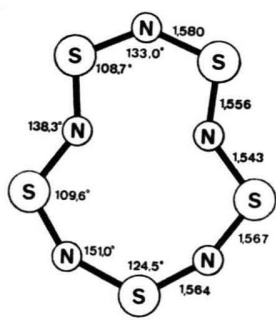

$\mathrm{S}_{5} \mathrm{~N}_{5}^{+}$ 

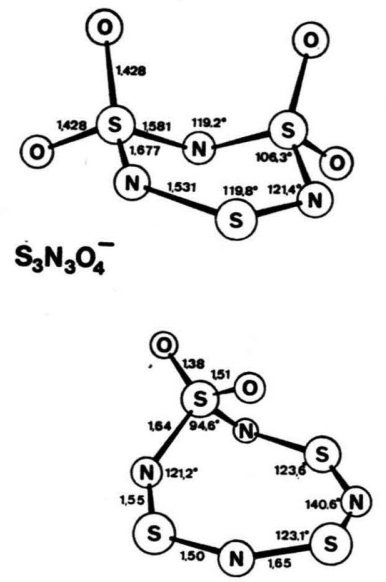

$\mathrm{S}_{4} \mathrm{~N}_{4} \mathrm{O}_{2}$

The ionic species can be formally regarded as being formed according to the following equation:

$$
2 \mathrm{~S}_{4} \mathrm{~N}_{4} \mathrm{O}_{2} \rightarrow \mathrm{S}_{5} \mathrm{~N}_{5}^{\oplus}+\mathrm{S}_{3} \mathrm{~N}_{3} \mathrm{O}_{4}^{\ominus}
$$

The ionic compound crystallizes with a monoclinic cell, space group $\mathrm{P}_{2_{1}} / \mathrm{c}$ and four units of $\mathrm{S}_{5} \mathrm{~N}_{5}+\mathrm{S}_{3} \mathrm{~N}_{3} \mathrm{O}_{4}-$ per cell. The shape of the $\mathrm{S}_{5} \mathrm{~N}_{5}{ }^{+}$ cation observed, differs greatly from the heartshaped ion reported for $\mathrm{S}_{5} \mathrm{~N}_{5}{ }^{+} \mathrm{AlCl}_{4}{ }^{-18}$.

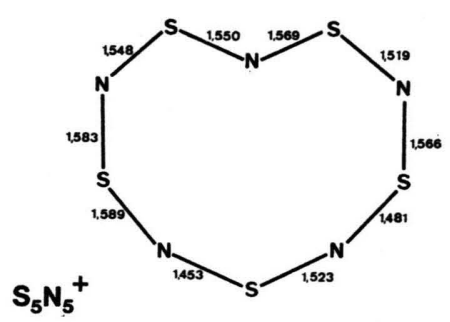

1 H. W. Roesky, Chemiker-Ztg. 98, 121 [1974].

2 H. W. Roesky and B. KuHTZ, Chem. Ber., in press.

3 H. W. Roesky and H. Wiezer, Angew. Chem. 85, $722[1973]$.

$4 \mathrm{H}$. W. Roesky and H. Wiezer, Chem. Ber. 107, 3186 [1974].

5 B. Krebs, University of Bielefeld, unpublished results.

6 H. W. Roesky and E. Wehner, Angew. Chem., in press.

7 H. W. Roesky and H. Wiezer, Angew. Chem. 87, 254 [1975].

8 H. W. Roesky and G. Holtschneider, unpublished results.

9 H. W. Roesky and E. JAnssen, Chemiker-Ztg. 98, 260 [1974].
The ring is almost planar and the bond distance across the ring are the same within experimental error. The S-N bond lengths are in the range 1.543-1.580 $\AA$ and are normal for a delocalized S-N system, compared with the values of 1.548-1.566 $\AA$ in the $\mathrm{S}_{4} \mathrm{~N}_{3}{ }^{+}$ion.

The $\mathrm{S}_{3} \mathrm{~N}_{3} \mathrm{O}_{4}{ }^{-}$anion contains an $\mathrm{S}_{3} \mathrm{~N}_{3}$ ring with two terminal oxygens on two of the sulfur atoms. Within experimental error, the ion shows $\mathrm{m}$ symmetry. The nitrogen atom situated between the two $\mathrm{SO}_{2}$ groups is displaced by $0.64 \AA$ out of the mean plane at the rest of the ring as a consequence of the nearly tetrahedral angles at these two sulfur atoms. The bond distances to this nitrogen atom indicate some multiple bonding and suggest that the negative charge is delocalized over the $\mathrm{SO}_{2}-\mathrm{N}-\mathrm{SO}_{2}$ system. The bond distances in the diimide $\mathrm{N}-\mathrm{S}-\mathrm{N}$ unit are very short, indicating substantial multiple bonding in this part of the ring where as the bonds joining this unit to the $\mathrm{SO}_{2}-\mathrm{N}-\mathrm{SO}_{2}$ portion of the ring lie within the range of $\mathrm{S}-\mathrm{N}$ single bonds.

$\mathrm{S}_{4} \mathrm{~N}_{4} \mathrm{O}_{2}$ crystallizes in the non-centrosymmetric space group $\mathrm{Abm} 2$ with eight molecules per cell. The molecule contains an eight-membered $\mathrm{S}_{4} \mathrm{~N}_{4}$ ring with both oxygens attached to the same sulfur atom. This atom lies $1.52 \AA$ and the two adjacent nitrogen atoms $0.41 \AA$ above the mean plane of the other ring atoms, which are coplanar to within $0.014 \AA$. The bonding could be described in terms of two sulfur diimide NSN fragments linked by $\mathrm{S}$ and $\mathrm{SO}_{2}$ bridges or, in view of the approach to planarity of the $\mathrm{N}_{4} \mathrm{~S}_{3}$ part of the ring, as a $10 \pi$ delocalized system linked into a ring by the $\mathrm{SO}_{2}$ group.

I wish to express my thanks to my collaborators. This work was supported by Fonds der Chemischen Industrie and Deutsche Forschungsgemeinschaft.

10 H. W. Roesky and E. Janssen, Chem. Ber. 108, 2531 [1975].

11 I. RAYMENT, unpublished results.

12 A. Zalkin, T. E. Hopkins, and D. H. Templeton, Inorg. Chem. 5, 1767 [1966].

13 D. B. Adams, A. J. Banister, D. T. Clark, and D. Kilcast, Int. J. Sulfur Chem. 1, 143 [1971].

$14 \mathrm{H}$. W. Roesky and H. Wiezer, Angew. Chem. 86, 130 [1974].

15 H. W. Roesky and H. Wiezer, Chemiker-Ztg. 97, 661 [1973].

16 G. ERTL and J. Weiss, Z. Naturforsch. 29 b, 803 [1974].

17 H. W. Roesky, W. Groose Böwing, I. Rayment, and H. M. M. Shearer, Chem. Commun. 1975, 735 .

18 A. C. Hazell and R. G. Hazell, Acta Chem. Scand. 26, 1987 [1972]. 